УДК 316.2:327

DOI https://doi.org/10.32840/2707-9147.2020.86.2

Т. М. ІВАНЕЦЬ

кандидат політичних наук, старший викладач кафедри філософії та соціології

Маріупольський державний університет

\title{
ОСОБЛИВОСТІ СТАНОВЛЕННЯ ТА ПЕРСПЕКТИВИ РОЗВИТКУ СОЦІОЛОГІЇ МІЖНАРОДНИХ ВІДНОСИН
}

У статті досліджено особливості становлення та передумови формування сочіології міжнародних відносин у 60-ті роки ХХ століття, визначено основні етапи ї̈ інституалізації. Зазначено, щзо особливістю сочіологічного підходу $\epsilon$ вивчення міжнародних відносин як форми суспільних відносин з акцентом на сочіальні фактори: національні норми, традииії, ідеології, культури, а не виключно національні інтереси. Проаналізовано діяльність франиузької сочіологічної школи міжннародних відносин та ї̈ основних ідеологів: Р. Арона (прихильник політичного реалізму, засновник сочіології міжнародних відносин) та Г. Бутуля (засновник полемології - соиіології війни). Визначено особливості соиіології миру (іренології) норвежського сочіолога Й. Галтунга, охарактеризовано поняття «ізоморфізм» та його застосування під час аналізу міжнародних відносин. Проаналізовано особливості концепчиї «міжнародного суспільства», яку розробляла англійська сочіологічна школа міжнародних відносин (М. Уайт, Х. Булл). Розглянуто різницю між поняттяли «міжнародна система» та «міжнародне суспільство». Визначено передумови виникнення потреби у комплексному вивченні питань безпеки. Досліджено теорію сек'юризації копенгагенської сочіологічної иколи міжнародних відносин (Б. Бузан, О. Вейвер) в межах формування соиіального підходу по питань безпеки. Розглянуто особливості та передумови виникнення конструктивістського підходу в дослідженні міжнародних відносин на межі 80-90-х рр. ХХ століття. Проаналізовано теорію А. Вендта щзодо формування ідентичностей у процесі соціалізації та ідею руху міжнародних відносин у бік створення світової держсави. Розглянуто перспективні напрями розвитку соиіології міжнародних відносин на сьогоднішньому етапі в умовах розвитку глобалізачійних процесів та формування нового світового порядку.

Ключові слова: сочіологія міжнародних відносин, міжнародне суспільство, міжнародна система, міжнародний конфлікт, сочіологія миру, сочіологія війни, теорія сек'юризаиії.

Постановка проблеми. Сфера міжнародних відносин на сучасному етапі динамічно розвивається та швидко змінюється, що змушує наукову спільноту шукати нові підходи для ефективного дослідження міжнародних процесів. Характерною рисою сучасної системи міжнародних відносин є стабільне зростання ролі соціального складника та тенденція до формування єдиної глобальної спільноти - глобального

(C) Т. М. Іванець, 2020 
суспільства. В цих умовах соціологічний підхід до вивчення міжнародної проблематики набуває актуальності, що створює сприятливе підгрунтя для активного розвитку соціології міжнародних відносин, дисципліни, яка сформувалась у другій половині XX століття на стику політології та політичної соціології.

Аналіз останніх досліджень і публікацій. Соціологічний підхід сьогодні використовується під час дослідження різноманітних складових елементів системи міжнародних відносин, тому є вже доволі грунтовний науковий доробок із цієї проблематики. Загальнотеоретичні аспекти соціології міжнародних відносин розглянуті в чисельних працях П.А. Циганова, А.Г. Дугіна; аналізу акторів міжнародних відносин із позиції соціологічного підходу присвячені дослідження А.Е. Кутейникова, І.Ю. Кисельова, А.Г. Смирнової; проблема дослідження міжнародного порядку в соціології міжнародних відносин розглядається I.П. Щевелем; соціологічним осмисленням питань безпеки та загроз займаються А.Г. Смирнова, Л.В. Калашнікова; особливості використання соціологічного методу в дослідженні міжнародних відносин аналізує Н.В. Терещенко. Однак, ураховуючи активні зміни, які відбуваються в сучасній системі міжнародних відносин, є потреба визначити перспективи подальшого розвитку соціології міжнародних відносин, що можливо зробити лише спираючись на детальний аналіз основних етапів їі становлення.

Мета статті. Головною метою цієї роботи $\epsilon$ аналіз особливостей становлення та визначення перспективи подальшого розвитку соціології міжнародних відносин.

Виклад основного матеріалу. Виникнення соціології міжнародних відносин тісно пов'язано з розвитком теорії міжнародних відносин, періодом зародження якої вважають 20-30 роки ХХ століття. Формування нового світового порядку після Першої Світової війни стало поштовхом для розвитку досліджень у сфері міжнародних відносин. Становлення теорії міжнародних відносин характеризувалось протистоянням ідеалістичного та реалістичного напрямів досліджень, загострення якого припало на 30-ті роки XX століття та відбувалось на фоні неефективності чинної системи міжнародних відносин. На тлі актуалізації загрози фашизму та комунізму укріплюються позиції політичного реалізму. Після Другої Світової війни він стає не лише провідною течією в теорії міжнародних відносин, але й основою зовнішньополітичної доктрини США.

Таке домінування реалізму не лише в теорії міжнародних відносин, але й у реальній політиці сприяло швидкому розчаруванню в його доктринах, зростанню невдоволення в академічних кругах, та як наслідок - виникненню нових напрямів та шкіл у теорії міжнародних відносин. Наприклад, із кінця 50-х років XX століття активно розвиваються модерністські теорії, які протиставляють себе політичному реалізму та проголошують своєю метою звільнення теорії міжнародних відно- 
син від абстрактних категорій та догм політичного реалізму, прагнучи перетворити їі на точну науку, котра б була об’єктивною та незалежною від позиції дослідника. Крім того, загострення протистояння між капіталістичним та соціалістичним таборами, розгортання національно-визвольного руху у країнах «третього світу» вимагало пошуку принципово нових методів, які б дозволили ефективно дослідити та спрогнозувати подальший перебіг подій у міжнародній системі. В цих умовах на початку 60-х років XX століття починає оформлюватись соціологія міжнародних відносин.

Формально інституалізація соціології міжнародних відносин відбулась у 1966 році на VI Всесвітньому соціологічному конгресі у Гвіані, де було заслухано спеціальну доповідь, яка обгрунтовує становлення нової наукової галузі, а на VII Конгресі в 1970 році було прийнято рішення про створення в рамках Міжнародної соціологічної асоціації Дослідницького комітету із соціології міжнародних відносин [1].

Засновником соціології міжнародних відносин уважають французького соціолога Р. Арона, який ще в першій половині ХХ століття виказував ідеї про необхідність формування подібного наукового напряму. Особливістю соціологічного підходу до вивчення міжнародних відносин було те, що міжнародні відносини розглядались як форма суспільних відносин. Великого значення в соціології міжнародних відносин набували соціальні фактори: національні норми, традиції, ідеології, культури, а також національні інтереси. Тобто вивчення міжнародних відносин та тенденцій їх розвитку відбувалось із позицій соціального.

Особливістю досліджень Р. Арона $є$ його прихильність веберівській традиції та політичному реалізму. Він уважав, що застосування сили та конфліктність є характерними рисами міжнародних відносин: на відмінну від суспільних відносин усередині держави, які розвиваються в межах соціального консенсусу, міжнародні відносини реалізуються на тлі війни. Водночас, незважаючи на прихильність Р. Арона до ідей політичного реалізму, він не вважав національні інтереси чимось постійним: вони можуть змінюватись залежно від ситуації, хоча деякі 3 них, наприклад, безпека, бувають більш тривалими. Р. Арон виділяв три структурних виміри міжнародних систем: конфігурацію співвідношення сил; ієрархію акторів та гомогенність чи гетерогенність складу, причому головним виміром він уважав конфігурацію співвідношення сил (підкріплення цієї тези дослідник бачив в існуванні «центрів сили» в міжнародній системі). Враховуючи, що соціологія міжнародних відносин має своїм предметом поведінку акторів на міжнародній арені, ii головним завданням є вивчення закономірностей та різних змінних, котрі визначають політику окремих держав та перебіг міжнародних подій та процесів, визначення впливу режимів та ідеологій на міжнародні відносини. В результаті це дозволить визначити не лише правила гри, але й соціальні типи міжнародних конфліктів та закони розвитку певних міжнародних ситуацій [2]. 
Другим напрямом французької соціології міжнародних відносин стала полемологія Г. Бутуля. Ії ключовим завданням було об’єктивне вивчення воєн як соціального феномену, базуючись на необхідності історичного осмислення дійсності та максимального уникнення політичного підходу. Г. Бутуль відносив до причин військових конфліктів порушення рівноваги між суспільними інститутами; політичні сили, які виникли внаслідок порушення рівноваги; випадкові причини та мотиви; агресивність та войовничість як психологічна проєкція соціальних груп; ворожість та войовничі комплекси. Серед войовничих комплексів дослідник виділяв такі: «комплекс Абрахама» - несвідоме бажання принести власних дітей у жертву власним потребам; «комплекс цапа-відбувайла» - перенесення страхів та невдоволення на зовнішнього ворога; «Дамоклів комплекс» - почуття незахищеності, що викликає неконтрольовану паніку та внутрішнє згуртування держави [3].

Полемологію (соціологію війни) традиційно прийнято протиставляти іншому напрямі в соціології міжнародних відносин - соціології миру (іренологіi), яка також сформувалась у 60-ті роки XX століття. Ïї засновником вважається норвежський соціолог Й. Галтунг, який розробив у межах соціологічного підходу до вивчення міжнародних відносин методологію мирного вирішення міжнародних конфліктів, яка й отримала назву «іренологія». В його аналізі міжнародних конфліктів ключовим є поняття ізоморфізму (подібності), яке передбачає, що кожному елементу однієї структури відповідає лише один елемент іншої. Дотримуючись поняття ізоморфізму, Й. Галтунг говорив про подібність малих соціальних груп та міжнародних систем (ізоморфні поняття). Він стверджував, що міжнародна система є соціальною структурою, елементи якої взаємодіють на національному рівні, а ізоморфізм має виступати інструментом прикладного аналізу структурної взаємодії в міжнародних відносинах. Причину міжнародних конфліктів Й. Галтунг бачив у структурному насиллі, залежністю між рангом та взаємодією, ранговій невідповідності. На його думку, найбільш ефективним способом припинення війни $є$ трансформація внутрішніх структур ворожих сторін, а вирішення конфлікту полягає в моделюванні позитивного миру на противагу негативному миру, який не виключає повторення війни [4].

Англійська соціологічна школа міжнародних відносин у 60-ті роки XX століття починає розробляти концепцію міжнародного суспільства, яка базувалась на суспільному характері міжнародних відносин, тобто на соціальних відносинах між державами. В межах цієї школи, перш за все, треба відзначити дослідників М. Уайта та Х. Булла, котрі розглядали міжнародну систему як соціальне середовище (суспільство), що регулюється спільними нормами. У роботі «Анархічне суспільство: вивчення порядку в світовій політиці» Х. Булл говорив про відмінність міжнародної системи та міжнародного суспільства. Коли держави 
(дві або більше) мають достатню кількість контактів, але не пов'язані спільними цінностями та інститутами, формується міжнародна система. Коли ж держави встановлюють спільні правила, інститути, формати поведінки, цінності та визнають загальну зацікавленість у підтримці цих домовленостей - виникає міжнародне суспільство. Ці норми проявляються в низці інститутів, які формують міжнародне суспільство: війна, дипломатія, баланс сил, міжнародне право, система управління великих держав тощо. Міжнародній системі та міжнародному суспільству притаманні різні типи балансу сил. Міжнародній системі, де немає спільних інтересів і глобальних інститутів, притаманний ситуативний, нестійкий баланс сил, водночас міжнародне суспільство характеризується свідомо сконструйованим балансом сил. Таким чином, саме соціальні зв'язки, котрі пов'язують держави, забезпечують порядок у світовій політиці. Цей порядок підтримується заради стабільності та безпеки [5].

У 1970-80-ті роки ХХ століття, в умовах продовження Холодної війни та збільшення ролі економічних, екологічних та ідеологічних факторів у міжнародних відносинах, виникає потреба в комплексному підході до вивчення питань безпеки. Соціального підходу до питань безпеки, який передбачав переміщення акценту з держави на людину, дотримувалась Копенгагенська школа міжнародних відносин. Саме в iï межах була створена теорія сек'юризації. Один із іiі засновників Б. Бузан - розглядав безпеку як відносне поняття. Процес, під час якого об’єкт починає вважатись загрозою безпеці, Б. Бузан називав сек'юризацією. Він відбувається у два етапи: перший - актор повідомляє про наявність загрози, другий - легітимізується факт порушення чинних норм після усвідомлення суспільством реальності загрози. Успішність сек'юризації залежить від внутрішніх та зовнішніх умов. Б. Бузан уважав, що в межах міжнародних відносин певне явище отримує статус загрози безпеки не тому, що несе в собі об'єктивну загрозу, а тому, що актор визначає його як екзистенціальну загрозу об'єкту безпеки. Коли йдеться про загрозу безпеці держави, частіше за все $є$ лише загроза правлячому режиму, який подає іï як загрозу всьому суспільству та таким чином виправдовує свої дії. Тому Б. Бузан уважав, що питання безпеки необхідно аналізувати не через оцінку характеру реальних загроз, а через вивчення процесу сек'юризації - хто, що, навіщо та за яких умов сек'юризує [6].

Продовжив розвивати теорію сек’юризації О. Вейвер, який об’єднав усі елементи безпеки у дві групи: державна безпека (те, що стосується державного суверенітету) та соцієтальна безпека (те, що стосується суспільства та його ідентичностей). Щоб проблему віднести до безпеки, ïi треба спочатку політизувати, зробити обговорюваною, а вже потім визнати екзистенційною загрозою. Однак він зазначав: якщо дискурс може створювати ситуацію небезпеки, то можливо говорити і про зворотний процес - десек'юритизацію [6]. 
Закінчення холодної війни, руйнація Ялтинсько-Постдамської системи міжнародних відносин, активізації процесів глобалізації - все це, з одного боку, створювало умови для розвитку соціології міжнародних відносин, а з іншого - вимагало трансформації ії підходів та проблематики. Наприкінці $80-\mathrm{x}$ - початку 90 -х років XX століття в соціології міжнародних відносин формується конструктивістський підхід, у межах якого міжнародні відносини розглядаються як соціальний конструкт, а актори виступають творцями соціальної реальності, яка формується залежно від їх цінностей, переконань, матеріальних речей. Причому вирішального значення набувають саме ідейні конструкції.

Представником конструктивістської школи соціології міжнародних відносин є А Вендт. У своїй роботі «Соціальна теорія міжнародних відносин» він говорив про те, що суб'єкти формують розуміння власної ідентичності та сприйняття інших у процесі соціальної взаємодії, тобто ідентичності формуються та змінюються у процесі соціалізації. А. Вендт дотримувався державоцентризму, тобто вважав державу ключовим актором міжнародних відносин. Соціальні ідентичності держав або колективні ідентичності формуються нормами та ідеями чинної міжнародної системи, саме ідентичності є основою інтересів держав. Важливість тих чи інших цінностей визначається тим значенням, якого їм надають актори. Об'єктивні явища в міжнародних відносинах також можуть змінюватись так само, як і характер взаємодії акторів, приймаючи форму конфліктних або дружніх відносин. Міжнародна система є соціальною категорією, яка конструюється у процесі міжнародної взаємодії, тому її анархічний характер не може бути незмінною характеристикою. А. Вендт уважав, що міжнародні відносини будуть рухатись у бік створення світової держави. Розвиток міжнародної системи буде націлений на забезпечення стабільності, безпеки та взаємного визнання акторів, а бажання отримати безпеку сприятиме утворенню спільної колективної ідентичності. На думку дослідника, розвиток міжнародної системи буде рухатись за таким сценарієм: культура системи держав, спільнота держав, глобальне суспільство, Кантова культура колективної безпеки, єдина світова держава [7].

На сьогодні розвиток міжнародних відносин відзначається цілою низкою нових тенденцій, пов'язаних із формуванням нової системи міжнародних відносин, яка має прийти на зміну біполярної. Серед них можна виділити такі: розмивання кордонів між внутрішньою й зовнішньою політикою; активізація процесів демократизації у світових масштабах; зростання кількості та урізноманітнення акторів міжнародних відносин; зміщення акценту у структурі загроз безпеці у бік загроз м'якої сили; виникнення нових механізмів регулювання міжнародних відносин; зростання ролі інформації; існування протилежних тенденцій до інтеграції та дезінтеграції; фрагментація міжнародних відносин. 
Крім того, спостерігається тенденція до глобалізації міжнародного життя, зростання універсальності, взаємозалежності та взаємозумовленості сучасних міжнародних відносин, активізація процесу створення глобального суспільства, й водночас зростання конфліктності у світі через культурно-цивілізаційні розбіжності та загострення наявних проблем та суперечностей [8]. Усе це вимагає вироблення нових підходів до дослідження міжнародних відносин з урахуванням усіх вищезазначених феноменів та тенденцій.

Перспективи розвитку соціології міжнародних відносин пов'язані, перш за все, з підходом до інтерпретації світу як єдиного простору, який структурований різноманітними соціальними взаємодіями, що здійснюються на шляху до формування глобального суспільства. В межах цього підходу міжнародні відносини аналізуються з урахуванням ролі соціальних норм та інститутів, групових цінностей, ідентичностей, культур, традицій тощо, які й мотивують сторони брати участь у міжнародній взаємодії.

Актуальною залишається проблема дослідження міжнародного конфлікту, особливо враховуючи той факт, що в нових реаліях держава перестає бути основним суб'єктом, який використовує нелегітимне насилля на міжнародній арені. Зокрема важливо виробити механізми запобігання конфліктам як з участю держав, так і з участю інших соціальних спільнот, коріння яких лежить у зіткненні моралі, традицій, звичаїв та ідентичностей. Поряд із дослідженням міжнародного конфлікту, соціологія міжнародних відносин продовжує вивчати міжнародну співпрацю в контексті взаємодії соціальних спільнот, аналізуючи внутрішні причини, шляхи реалізації, основні форми та можливі наслідки.

Також до перспективних напрямів сучасної соціології міжнародних відносин належать дослідження інтеграційних та дезінтеграційних процесів, які супроводжуються виникненням нових спільнот, ідентичностей, цінностей; вивчення особливостей нових акторів міжнародних відносин та їх впливу на систему загалом, особливо роль особистості, терористичних груп, інтернет-спільнот тощо; аналіз процесу демократизації міжнародних відносин, поширення демократичних цінностей, зростання ролі моральних та правових факторів у міжнародних відносинах.

Висновки і пропозиції. Виникнення соціології міжнародних відносин у 60-ті роки XX століття стало, з одного боку, відповіддю на нові виклики, котра породжувала біполярна система міжнародних відносин, а з іншого - паралельно з розквітом модерністських підходів, реакцією на розчарування в політичному реалізмі, який зайняв у цей час панівні позиції в теорії міжнародних відносин. Саме соціологічний підхід дозволив уключити в аналіз нові феномени, які активно виникали в системі міжнародних відносин (недержавні актори міжнародних відносин, зростання ролі соціальних факторів, виникнення 
нової структури загроз тощо). Соціологічний підхід чудово вписується і в сучасні тенденції розвитку міжнародної системи. Процеси глобалізації та зближення світу, які поступово ведуть до формування глобального суспільства, створюють для соціології міжнародних відносин нове поле для досліджень, адже саме соціологічний метод дозволить найбільш ефективно проаналізувати ці процеси.

\section{Список використаної літератури}

1. Шевель І.П. Основні напрями вивчення міжнародного порядку в соціології міжнародних відносин. «Молодий вчений». № 4.1(31.1). Квітень, 2016 р. С. 14-18. URL: http://molodyvcheny.in.ua/files/journal/2016/4/168.pdf

2. Цыганков П.А. Политическая социология международных отношений: учебное пособие. Москва: Радикс, 1994. 320 c. URL: https://www.gumer.info/ bibliotek_Buks/Polit/cugan/index.php.

3. Соловьев А.В. Полемология - французская социология войны. URL: http://ecsocman.hse.ru/data/312/991/1219/019_Solovev._A_V.pdf.

4. Каримова А.Б. Социология международных отношений в парадигмах поведения и деятельности. URL: https://www.imemo.ru/files/File/ru/Articles/2018/Nauka Kultura_Obshchestvo_2018_Nomer_2_Karimova.pdf.

5. Шинкарук К.С. Конструктивістська парадигма в дослідженнях міжнародних відносин: сутність і перспективи розвитку. URL: http://socio-journal.kpi.kiev.ua/ archive/2009/3/17.pdf.

6. Калашнікова Л.В. Аналітичне осмислення етапів інституціоналізацї соціології Кузик П.М. Конструктивіствька концепція А. Вендта: від критики «міжнародної анархії» до ідеї невідворотності світової держави. Вісник Львівського університету. Серія міжнародні відносини. 2013. Випуск 32. С. 98-103. URL: https://intrel.lnu.edu.ua/wp-content/uploads/2015/10/VLNU Mv 201332 15.pdf.

7. Троян C.C. Сучасні міжнародні відносини: основні тенденції еволюції URL: http://vmv.kymu.edu.ua/v/08/troyan_ss.htm.

Ivanets T. M. Features of formation and prospects of development of sociology of international relations

The article examines the features and prerequisites for the formation of sociology of international relations in the 60 s of the twentieth century, identifies the main stages of its institutionalization. It is noted that the sociological approach considers international relations as a form of social relations. The activity of the French sociological school of international relations and its main ideologues is analyzed: R. Arona (supporter of political realism, founder of sociology of international relations) and G. Butul (founder of polemology - Sociology of War). The features of Sociology of Peace (irenology) of the Norwegian sociologist $J$. Galtung are determined, the concept of "isomorphism" and its application in the analysis of international relations are characterized. The features of the concept of "international community", which was developed sociological English School of International Relations, are analyzed. (M. White, H. Bull). The difference between the concepts of "international system" and "international community" is considered. Prerequisites for a comprehensive study of security issues are identified. Theory of securitization of the Copenhagen sociological school of international relations 
(B. Buzan, O. Weaver) within the formation of a social approach to security issues is studied. The preconditions for the formation and features of the constructivist approach to the study of international relations at the turn of the 80-90s of the twentieth century are considered. A. Wendt's theory on the formation of identities in the process of socialization and the idea of the movement of international relations towards the creation of a world state are analyzed. The prospects of development of sociology of international relations in the conditions of development of globalization processes and formation of a new world order are considered.

Key words: sociology of international relations, international community, international system, international conflict, Sociology of Peace, Sociology of War, theory of securitization. 